\title{
FRAMEWORK OF CONTRADICTIONS SHAPING BANK MANAGEMENT: A CONCEPTUAL PAPER
}

\author{
Marlena SMUDA-KOCOŃ \\ University of Economics in Katowice; marlena.smuda-kocon@ue.katowice.pl, ORCID: 0000-0003-0468-5708
}

Purpose: The paper is an attempt to enter the discussion in the subject literature on elucidating problems in the non-systemic approach to managing the bank as an organization. The purpose of the paper is to identify the contradictions within which banks are managed, and which are aggravated in contingency situations. Due to the sensitive matter of the services they provide, banks are institutions that require special attention particularly now, when the COVID situation is radically testing management quality.

Design/methodology/approach: The paper is the result of a literature review.

Findings: The epistemological studies conducted have culminated in a framework of contradictory determinants shaping bank management during fast-paced changes in market conditions. The theoretical construct proposed may be a point of departure for empirical verification and further analytic work on the capacity of banks to reconcile the antinomies identified in the paper.

Originality/value: The study makes it possible for managers to fill the knowledge gap with respect to areas and implications of the identified contradictions. Awareness of their existence and, as a result, management that supports processes for responding to a volatile environment is particularly useful in crisis situations. The proposed theoretical concept may be applied to identify antinomies or their lack in other areas of management research for various organization types.

Keywords: contradictions, bank management.

Category of the paper: Conceptual paper.

\section{Introduction}

As organizations, banks do not form a homogenous group. Neither does a general theory of bank management exist. Moreover, a review of the literature indicates that research on this topic is developing in different directions (liquidity, bank value, capital and risk management to name only some). In practice, the various ways of managing banks are influenced by numerous 
exogenous and endogenous factors. These determinants mean that bank management has a rapidly changing and complex nature.

At the same time, a review of the literature shows that scholars have deemed contradictions or paradoxes in management to be an important topic and are making efforts to define these terms and analyze their many dimensions. Contradictions such as those between the categories of cooperation and competition (Brandenburger \& Nalebuff, 1996; RazaUllah, Bengtsson, $\&$ Kock, 2014), stability and change (Farjoun, 2010), profit and goal (Jay, 2013), or innovation and utility (Miron-Spektor, Erez, \& Naveh, 2011) are only some of them.

Previous studies on identified contradictions in organization management have, however, primarily been focused on an aggregated level of analysis (Schad et al., 2017). From the perspective of findings from the subject literature, the topic of contradictions within which banks are managed are a research subject that requires a separate theoretical approach. There is a lack of studies that concentrate on the specific nature of financial institutions. This paper attempts to fill this research gap by putting the previous cognitive findings, which are the result of literature reviews, side by side with the reality of managing a bank in a volatile environment. The purpose of the paper is to identify the contradictions within which banks are managed, and which are aggravated in contingency situations.

Scholars (Bennett, and Lemoine, 2014; Mack et al., 2016) indicate that in conditions of volatility, uncertainty, complexity and ambiguity (a so-called VUCA world) conventional management requires constant verification. Economic practice also proves that managers are forced to look for solutions that will allow them to preserve continuity of operations also in new, often crisis situations (economic fluctuations, stock market collapse, pandemics and consequences of economic lockdowns). All these factors impact the degree of complexity involved in processes of managing a modern bank. In consequence, the awareness that contradictions exist in the management of the special organization that is a bank, and their proper leveraging, is currently gaining particular importance.

\section{Literature review}

As Choudhry (2018) notes, different aspects of banking have a highly varying nature, but regardless of whether the discussion concerns commercial or investment banking, the common goal of all banking operations is management that allows return on capital and appreciation of the banking business.

As Capiga (2010, pp. 16-17) indicates, irrespective of whether bank management is defined as a process, a system or a model, it always involves such specific features as: levels, functions, subject and orientation of management (Figure 1). 


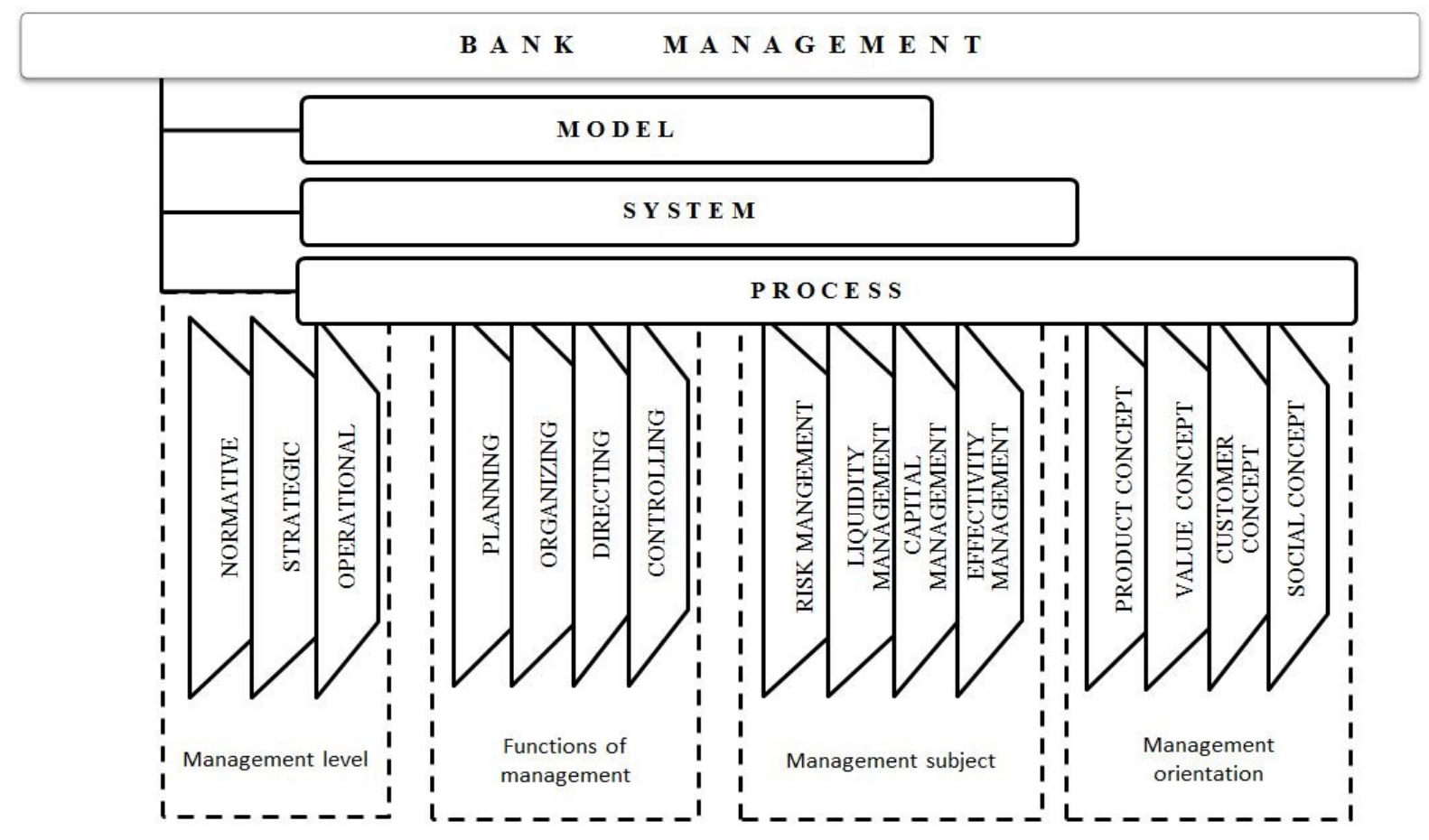

Figure 1. Bank management as process, system and model. Adapted from: Capiga M. (2010), Zarządzanie bankiem. PWN, Warszawa, pp. 16-17.

Even without delving into deeper analysis of the definitions proposed in the subject literature, it is clear that bank management is a complicated topic. Its level of complexity is increased by the fact that a bank is an organization that is simultaneously open and closed, modern and conservative, innovative and similar to others (Bakalarczyk, 2014) and thus requires rather special and constantly improved solutions that nevertheless remain linked to tradition (Bakalarczyk, 2013). Contradictions are an inherent element of these institutions' functioning.

The subject literature suggests that the existence of paradoxes should be used to build theories of management (Poole at al., 1989). Bloodgood (2010) perceives the need to manage contradictions and paradoxes from the perspective of their usefulness in organizational learning. Leclercq-Vandelannoitte (2013), meanwhile, indicates that integrating contradictions and paradoxes in change management is conducive to organizational development.

Antinomies in management and guidelines for effective operation were discussed already by Kotarbiński (1957) and Zieleniewski (1981). However, it is impossible to disagree with Lichtarski that amid the increasing dynamics and unpredictability of the environment their role is growing (Lichtarski, 2016).

A review of the subject literature indicates that the topic of contradictions in management has been analyzed in the context of entrepreneurship (Bratnicki, 2004), the decision-making and human capital management (Waldman et al., 2019), project management (Lichtarski, 2016), and strategic management processes. At the same time, Senge (1990) has written about tension, while other authors point to the existence of dilemmas in management (Hampden- 
Turne, and Trompenaars, 2000), dualisms or antinomies (Lichtarski, 2016). With respect to strategic management, paradoxes are also mentioned (De Wit, Meyer, 2007; Mesjasz, 2016). As regards the banking sector, researchers usually point out the existence of paradoxes in the area of risk management (Lim et al., 2016). While the topic of contradictions in enterprise management is nothing new, as it is rooted in philosophy (Oleksyn, 2013), academic studies investigate antinomies in bank management only fragmentarily.

For the purposes of this study it is assumed that contradictions in management are states of tension between logically justified elements that may be mutually exclusive. Therefore, decision-makers are faced with dilemmas (choice between $\mathrm{X}$ and $\mathrm{Y}$ ), have to deal with paradoxes (choice of $\mathrm{X}$ and $\mathrm{Y}$ ) or dialectics (if $\mathrm{X}$ and $\mathrm{Y}$ then $\mathrm{Z}$ ). A dialectic view of organizations is described among others by Nonaka (2002), while Cohen (1998) and Lewis (2000) talk of the nature of paradoxes inherent in the functioning of each organization.

The organization and management process may be treated as a sequence of choices between: flexibility and formalism, centralization and decentralization, an exploitation and an exploration-based approach, increasing activity and minimising interventions, an individual approach and routine action, increasing organization complexity and efforts to simplify (Smith, Lewis, 2011). According to De Witt and Meyer's (2007) concept, it is contradictions such as profitability vs. responsibility, logic vs. creativity, control vs. chaos and globalization vs. regionalization that form the basis for creating organizational strategy. Mechiche (2019) indicates three main areas of contradictions in business: leadership, strategy, and management and organizational paradoxes.

Contradictory theoretical assumptions and practical recommendations undoubtedly become fundamental principles of management in a complex world (Drucker, 1995). Furthermore, processes occurring in a volatile environment cause the rapid obsoleting of knowledge held. It becomes necessary to acquire knowledge on innovative management, and as Taleb (2020) indicates, the ability to mitigate unpredictability of phenomena and conquer chaos is gaining key importance. As a result, today it is banks that are the most serious challenge for managers. Faced with such high uncertainty they should revise their business strategies, also taking into account factors of an antinomic nature. Thus, in a further part of the paper selected contradictions of bank management have been identified and presented. 


\section{Result - framework of contradictions in management as a theoretical construct}

As a result of the literature review, contradictory determinants of bank management have been distinguished. Their significance is reinforced by the exogenous turbulence of the present epidemic. This turbulence, scholars suggest (Amankwah-Amoah et al., 2020), goes beyond past experience and knowledge due to its unpredictability and complexity.

The first antinomy is a consequence of the need to consider the legal environment, both local and international, in real solutions to bank management problems. It is not possible to apply the rules of the free market game to bank operations. Relaxing the principle of being guided in bank operations not by economics only brought disastrous economic consequences in the long term: the speculation bubble effect (Mukherjee, 2019). The rules of the bank "market game" are regulated by law and by special institutions established for that purpose (e.g. central bank, supervisory commissions). Although there is the contemporary bitcoin experiment, bitcoin trading is regulated by a law instituted by the interested parties themselves (and not by the legislature or government). In their decisions, bank management boards must take into account social and political responsibility. Particularly after the last financial crisis, much is being said about paying attention to certain bank products and services (e.g., mortgages), establishment of bank holdings in place of investment banks and the need to develop new analytical measures for the effects of bank operations (Koch, and McDonald, 2010). It has even been suggested that a new paradigm should be devised for bank management, according to which banks should build public confidence (Koch, and McDonald, 2010).

The consequences of such an orientation for bank managers' decisions also include the requirement of management procedure transparency and efforts to guarantee relatively high social responsibility of decision-makers for the economic risk taken. The modern bank is an almost ideal example of the systemic nature of economic relationships in the supra-regional dimension. The fall of a small, regional bank leads to serious problems and causes reactions on many different markets and on a far larger scale than the region in which the bank's customers are situated. A small bank does not mean small management problems, as is the case for a manufacturing micro-business. This is why guarantee funds whose purpose is to protect the system from catastrophe are created and national governments undertake rescue actions, generating public debt (very visible particularly during the current pandemic). Having a global and a systemic nature, which are features of the modern financial markets, must be recognized as important to bank management. Taking this into account means that on the one hand banks must comply with universal principles and grow similar (mimetics, emulation), and on the other they have their separate institutional logic (Lawrynowicz, 2013) and have to build a brand- and product-based competitive advantage (Piocha, and Radlińska, 2008). In banks, similarities to others and differences are visible for instance in structural solutions (Flejterski, 1999) and products (Grzegorczyk, 2001). 
Second, the bank's products and business itself are becoming increasingly complex. Banks have links with insurance and leasing companies. They are entities that create so-called financial engineering and mixed (e.g., private-public) capital. Complexity, intangibility and high pace of changes in bank products and services lead to special challenges with respect to employee skills, operation flexibility, monitoring competitor activity, innovation, but also data protection and loyalty to the institution and the customer. Hundreds of regulations impact bank activity not only externally, but also internally in the case of regulations created for the needs of management, particularly in times of economic turbulence. They should all be coherent and solve any contradictions. Fluent operation within the field of legal provisions, control, the market and internal processes are a key competence for bank executives (Gup, 1995). At the same time, being institutions that require public confidence, banks are obliged to protect access to information and to money itself, while meeting process transparency and disclosure requirements. Thus, another dilemma that decision-makers have is reconciling the transparency requirement with the need to ensure security of information and funds.

A central position in the bank's assets seems to be held by capital. Until recently, the financial capital of a bank played the key role. It is the raison d'être of the bank as an institution. Undeniably, in every financial institution it is primarily money that counts. Consequently, banks in particular are assessed through the lens of financial indicators and financial assets held. On the other hand, however, particularly after the crisis of the first decade of the 21 st century, other constituents of the organization's total capital are also considered to be important. As many authors indicate, banks are institutions in which intellectual capital plays an equally important role to financial capital (Nosowski, 2013). Because of problems with the valuation of banks' financial assets and of risk, as well as unfair practices of measurement institutes, relational, organizational and human capital have also caught decision-makers' attention. The great importance of assessing intellectual capital in banks is related to the intangible nature of banking services. Potential customers judge a bank based on the quality of services it provides, which are a function of the knowledge, competence and skills of the bank's employees. The question in economically unstable times is, to what extent will decision-makers be willing to invest in intellectual capital, and to what extent will normalizing the financial situation be the priority. It is commonly said that it is necessary to replace the authoritarian and control-driven management style by participatory management, a focus on entrepreneurship and opportunity-taking. Independence favors seizing opportunities as they appear, but is also related to higher risk.

Banks are undoubtedly entities that focus primarily on the performance of commercial goals. In the current pandemic situation, their role also includes distribution of special aid programmes, carried out in cooperation with state institutions. The present extraordinary circumstances force the banking sector to undertake above-standard action. Meeting the challenges set by the present requires flexibility while maintaining a stable capital position and liquidity. On the one hand, the inevitable changes in the area of digitalization of bank activity require adequate means for implementing investments. On the other, however, the dynamic 
increase in safety regulations may cause innovation to slow - a phenomenon that can also in itself be a source of risk. It is the management that ultimately decides whether to seize the opportunities that appear, or conversely to adopt a conservative, cautious attitude for uncertain times. Many more of these kinds of antinomies may be cited (Oleksyn, 2013). Only some of them are included in Figure 2, but the list remains open.
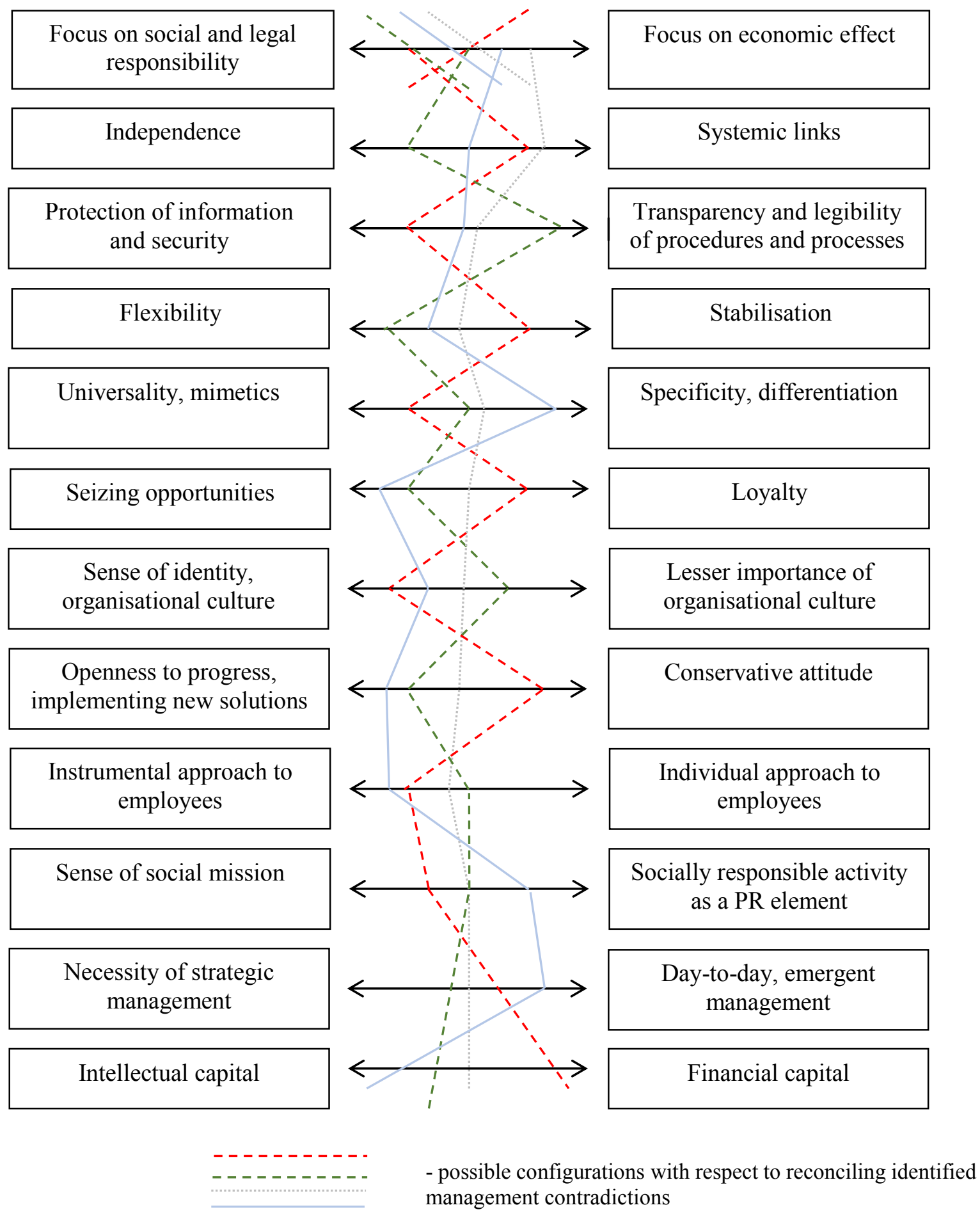

Figure 2. Framework of contradictions shaping bank management. Own compilation. 
The issue of creating a positive image by banks also remains to be addressed. On the one hand, banks have been taking socially responsible action from the start of the pandemic, but on the other, in contingencies the planning of protective measures (redundancies, changes in the credit portfolio, etc.) becomes inevitable. The factors determining which solutions will be adopted doubtless include bank size, its scope of activity and finally the level of decision makers' awareness. Contradictions may also emerge in the attitudes of executive staff. On the one hand some are visionary leaders, while on the other administration-driven leaders are mentioned (Bratnicki, 2002, pp. 98).

Importantly, the management may adopt solutions that are mid-way between the indicated extreme situations. This makes the number of possible configurations unlimited, and establishing what course they will take is particularly interesting in various turbulent conditions.

It seems interesting to establish how these configurations take shape in the case of individual banks during financial turbulence (example of the 2008-2010 crisis) or unforeseen upheavals due to the current pandemic. The management may strive to establish a state of balance between the identified incompatible areas of activity by adopting intermediary, compromise-based solutions. The existence of contradicting guidelines does not mean that in every instance, one solution has to be chosen in a dichotomous manner (Lichtarski, 2016). Bank managers often have to reconcile the identified contradictions. Thus standardization of certain actions must coexist with the possibility of undertaking atypical projects and solving problems unconventionally (Kousholt, 2007). Intellectual capital should be supported by the appropriate material capital, and focus on economic effect should not preclude socially responsible operations. It may be expected that depending on the external and internal determinants present, the point of gravity will move towards one extreme.

All the above determinants, but also many more specific ones (e.g. macro: those related to ideology, fashion; mezzo: to the political system, economic opportunities, development of information technologies, openness to capital flow; micro: to individuals and situations) mean that bank management is quite dynamic and requires a constant search for original and innovative solutions.

\section{Discussion}

In management we encounter various contradictions, and only selected examples have been presented above. Many of the principles of management fall somewhere between the extremes of categories like change management - stabilization, control - autonomy, permanence flexibility. 
It should be noted that the proposed theoretical concept assumes a number of generalizations and may be treated as a point of departure for building other expanded variants. On the other hand, the high level of generality makes it possible to successively verify the topic and allows the observed antinomies to be described in more detail depending on the features of the organization studied. The high, negative pace of changes in the environment emphasizes the necessity of detecting and further analyzing them. The conditions present in the environment of modern organizations, which may lead to the intensification of the observed contradictions, support the need for even simplified studies. At the same time, in a period where much focus is placed on sustainable development, it should be considered whether it is harmony that is the most important measure of success, or rather the ability to deal with clashing forces (Bratnicki, 2002, p. 84).

\section{Summary}

The article uses the achievements of modern strategic management to identify contradictions in bank management. The priority for banks is to satisfy the demands placed on them by the COVID situation. Moreover, establishing and verifying which areas of bank management and their related contradictions are the most important in assessing a financial institution is not only a theoretical contribution, but also has practical implications. The structure of the research tool proposed in the paper may be the starting point for empirical verification and further analytic work on the capacity of banks to reconcile the antinomies identified in the paper. Analysis of banks' management operations and practices is a challenge for future research. Identifying whether and how far, according to the banks' judgement, regulatory pressure impedes innovation, or whether and how far the necessity of maintaining security standards in periods of turbulence in the environment hampers digital transformation and processes of technological and personal change has a key importance for future bank functioning. It becomes relevant to investigate whether and to what extent, under conditions of uncertainty and volatility of the environment, managers attempt to reconcile the identified contradictions and how effective any compromise-based solutions are. The proposed framework of contradictions opens a new research perspective for analyzing banks. 


\section{References}

1. Amankwah-Amoah, J., Khan, Z., Wood, G. (2020). COVID-19and business failures: The paradoxes of experience, scale and scope for theory and practice. European Management Journal, pp. 1-5. doi: 10.1016/j.emj.2020.09.002.

2. Bakalarczyk, S. (2013). Modern bank management. Lap Lambert Academic Publishing.

3. Bakalarczyk, S. (2014). Innovation Management by Banks. Warszawa: Difin.

4. Bennett, N., and Lemione, G.J. (2014). What a difference a word makes: Understanding threats to performance in a VUCA world. Business Horizons, pp. 1-7. doi:10.2139/ ssrn. 2406676.

5. Bloodgood, J.M., and Chae, B. (2010). Organizational paradoxes: dynamic shifting and integrative management. Management Decision, Vol. 48 No. 1, pp. 85-104. https://doi.org/10.1108 / 00251741011014472.

6. Brandenburger, A.M., Nalebuff, B.J. (1996). Co-opetition. New York: Doubleday.

7. Bratnicki, M. (2004). Organizational Enterpreneurshipscape: Contradictions, Processes, Dimensions, Forms and Questions. Dabrowa Gornicza: Academy of Business in Dabrowa Gornicza.

8. Capiga, M. (2010). Zarzadzanie bankiem. Warszawa: PWN.

9. Choudhry, M. (2018). An introduction to banking principles, strategy and risk management. Wiley: Chichester West Sussex.

10. Drucker, P.F. (1995). Zarządzanie w czasach burzliwych. Kraków: Wydawnictwo Akademii Ekonomiczne.

11. Eisenhardt, K.M., and Martin, J.A. (2000). Dynamic capabilities: What are they? Strategic Management Journal, Vol. 21, pp. 1105-1121.

12. Farjoun, M. (2010). Beyond dualism: Stability and change as a duality. Academy of Management Review, 35(2), pp. 202-225.

13. Flejterski, S. (1999). Różnicowanie struktur we współczesnej bankowości. Szczecin: WNUS.

14. Flejterski, S. (2012). Niestabilne equailibrium: w poszukiwaniu nowego paradygmatu w bankowości. In: I. Pyka and J. Cichorska (Eds.), Finanse $w$ niestabilnym otoczeniu dylematy $i$ wyzwania: bankowość (pp. 39-46). Katowice: Wydawnictwo Uniwersytetu Ekonomicznego.

15. Grzegorczyk, W. (2001). Produkty bankowe. Rozwój i sprzedaż. Warszawa: Biblioteka Menedżera i Bankowca.

16. Gup, B.E. (1995). The Bank Director's Handbook: The Board Member's Guide to Banking \& Bank Management, Hardcover: Irwin Professional Publishing.

17. Hampden-Turner, C., Trompenaars, A. (2000). Building cross-cultural competence: how to create wealth from conflicting values. Chichest: Wiley. 
18. Jay, J. (2013). Navigating paradox as mechanisms of change and innovation in hybrid organizations. Academy of Management Journal, 56(1), pp. 137-159.

19. Koch, T.W., MacDonald, S.S. (2010). Bank Management. Mason: Sounth Wester Cengage Learning.

20. Kotarbiński, T. (1957). Wybór pism, t. 1: Myśli o działaniu. Warszawa: PWN.

21. Kousholt, B. (2007). Project Management - Theory and Pracitice. Copenhagen: Narayana Press.

22. Ławrynowicz, W. (2013). Tożsamość organizacyjna banków spółdzielczych w Polsce. Ujęcie instytucjonalne. Warszawa: Poltext.

23. Leclercq-Vandelannoitte, A. (2013), Contradiction as a medium and outcome of organizational change: a Foucauldian reading. Journal of Organizational Change Management, Vol. 26, $n r$ 3, pp. 556-572, https://doi.org/10.1108/09534811311328579.

24. Lewis, M.W. (2000). Exploring Paradox: Toward a More Comprehensive Guide. Academy of Management Review, 25(4), pp. 760-776. doi: 10.5465/AMR.2000.3707712.

25. Lichtarski, J.M. (2016). Antynomie w zarządzaniu projektami. Prace Naukowe Uniwersytetu Ekonomiczne we Wrocławiu, nr 421, pp. 346-359.

26. Lim, Ch.Y., Woods, M., Humphrey, Ch., Seow, J.L. (2016). The paradoxes of risk management in the banking sector. The British Accounting Review, Vol. 49, pp. 75-90, https://doi.org/10.1016/j.bar.2016.09.002.

27. Luhmann, N. (1995). The paradoxy of observing system, Cultural Critique, No. 31, The Politics of Systems and Environments, Part II, pp. 37-55. Minneapolis: University of Minnesota Press.

28. Mack, O., Khare, A., Kramer, A., Burgartz, Th. (2016). Managing in a VUCA World. Cham Heidelberg: Springer.

29. Mechiche, M. (2019). Paradoxes of Business: Towards A Practice Model to Attend to Paradox Tensions in Organizations and Develop the Leaders of Tomorrow. International Journal of Applied Research in Management and Economics, 2(1), pp. 45-50.

30. Mesjasz, Cz. (2016). Paradoksy w systemowej teorii zarządzania. Prace Naukowe Uniwersytetu Ekonomicznego we Wrocławiu, nr 421, pp. 397-417.

31. Meyer, R., De Vit, B. (2007). Strategy Synthesis: Resoving Strategy Paradoxes to Create Competitive Advantage. Cengage Learning EMEA.

32. Miron-Spektor, E., Gino, F., \& Argote, L. (2011). Paradoxical frames and creative sparks: Enhancing individual creativity through conflict and integration. Organizational Behavior and Human Decision Processes, 116(2), pp. 229-240.

33. Mukherjee, S. (2019). Existence of Speculative Bubbles for the US at Times of Two Major Financial Crises in the Recent Past: An Econometric Check of BitCoin Prices. In: U. Hacioglu (Ed.), Blockchain Economics and Financial Market Innovation (pp. 475486). Springer. 
34. Nosowski, A. (2013). Modelowanie zorientowane biznesowo a kapitał intelektualny banku. Zarzadzanie i Finanse, $n r$ 2, pp. 406-417.

35. Oleksyn, T. (2013). Różne filozofie zarządzania. In: T. Oleksyn (Eds.), Filozofia a zarzadzanie (pp. 63-66). Warszawa: Wolters Kluwer.

36. Piocha, S., Radlińska, K. (2008). Konkurencja i konkurencyjność sektora banków komercyjnych. Zeszyty Naukowe Wydziału Nauk Ekonomicznych Politechniki Koszalińskiej, nr 12, pp. 119-132.

37. Poole, M.S., van de Ven, A.H. (1989). Using Paradox to Build Management and Organization Theories. The Academy of Management Review, Vol. 14, No. 4, pp. 562-578.

38. Raza-Ullah, T., Bengtsson, M., Kock, S. (2014). The coopetition paradox and tension in coopetition at multiple levels. Industrial Marketing Management, 43(2), pp. 189-198.

39. Schad, J., Lewis, M.W., Raisch, S., Smith, W.K. (2017). Paradox Research in Management Science: Looking Back to Move Forward. Academy of Management Annals, Vol. 10, No. 1, https://doi.org/10.5465/19416520.2016.1162422.

40. Senge, P.M. (1990). Piąta dyscyplina. Warszawa: PWN.

41. Smith, W.K., Lewis, M.W. (2011). Toward a Theory of Paradox: A Dynamic Equilibrium Model of Organizing. Academy of Management Review, 36(2), pp. 381-403. doi: 10.5465/ AMR.2011.59330958.

42. Taleb, N.N. (2020). Antykruchość: jak żyć w świecie, którego nie rozumiemy. Poznań: Wydawnictwo Zysk i S-ka.

43. Waldman, D.A., Putnam, L.L., Miron-Spektor, E., Siegel, D. (2019). The role of paradox theory in decision making and management research. Organizational Behavior and Human Decision Processes, Vol. 155, pp. 1-6.

44. Wit, B., Meyer, R. (2010). Strategy Synthesis: Resolving Strategy Paradoxes to Create Competitive Advantage. Cengage Learning EMEA.

45. Zieleniewski, J. (1981). Organizacja i zarządzanie. Warszawa: PWN. 